\title{
Gender Mainstreaming in Waste Education Programs: A Conceptual Framework
}

\author{
Letícia Sarmento dos Muchangos ${ }^{1,2, *(\mathbb{D})}$ and Philip Vaughter ${ }^{2}$ \\ 1 Graduate School of Media and Governance, Keio University, Kanagawa 252-0882, Japan \\ 2 Institute for the Advanced Study of Sustainability, United Nations University, Tokyo 150-8325, Japan; \\ vaughter@unu.edu \\ * Correspondence: leticia.muchangos@unu.edu
}

Received: 11 January 2019; Accepted: 1 March 2019; Published: 5 March 2019

\begin{abstract}
Gender issues are present in waste management, from daily handling activities through to decision-making processes. In waste education programs, the disregard for views of and contribution by women has resulted in strategies that do not comprehensively address the waste issue, preventing long-standing and sustainable outcomes, while increasing existing gender inequities. Three critical waste matters on education and gender were identified: (1) lack of meaningful involvement and participation of women (and other vulnerable groups) throughout the decision-making processes; (2) lack of inclusion of gender-specific designs and gender-sensitive approaches in the information and education materials; and (3) tendency to devise strategies directed to women only, while exempting the other stakeholders from their responsibilities. This paper presents a closer look into the relationship between waste education and gender, with a proposal of a participatory framework for gender mainstreaming in waste education programs. It includes components to assess the promoting entity of the waste education program and all stages of the program. The framework represents a novel theory and practice contribution for waste education development, to support academics, practitioners, and policymakers, in the quest of achieving equitable and sustainable waste management systems for all.
\end{abstract}

Keywords: gender and waste; gender mainstreaming; waste education

\section{Introduction}

On the gender-and-environment nexus, years of feminist theory have been calling for the development of "frameworks and perspectives that allow an understanding that women and men are not only affected by but also have important roles to play in, enabling environmental sustainability" [1]. It is argued in [2] that to improve the effectiveness of laws and regulations, the specific target groups affected-women and men with all identified gender aspects of cultural diversity-should be addressed appropriately with accompanying measures. Specifically, in environmental education, humans are commonly discussed as homogenous and ungendered, even though significant research has been informed by feminist perspectives [3]. For instance, on Acker's theory of the gendered organization, it is discussed how language, ideology, popular and high culture, dress, and media have been contributing for the gender division of labor [4]. Furthermore, though the division of labor between men and women is changing, women still hold most the responsibility for child-care, therefore having a substantial influence on the development of children's awareness of environmental issues, making women the first environmental educators for many $[5,6]$. Nevertheless, the knowledge and contribution of women to environmental research and frameworks have been systematically marginalized, resulting in strategies that are fundamentally gender-blind $[3,7,8]$. Gender blindness mainly refers to the "failure to recognize that the roles and responsibilities of women/girls and 
men/boys are ascribed to, or imposed upon, them in specific social, cultural, economic and political contexts" [9].

Concerning waste education, despite studies pointing to the influence of gender issues on the views, handling, and management of waste, related policies and programs mostly lack in the inclusion of gender perspectives [10]. Distinctively, there are three key issues surrounding gender and the development of waste education programs. First, the consistent lack of meaningful involvement and participation of women and other vulnerable groups throughout the decision-making processes of planning and implementation of the programs, neglecting their significant role as users and managers of natural resources and waste $[5,11]$. All the more so, in initiatives that consider community participation, "community" is usually seen as a homogenous group, therefore reproducing the unequal power dynamics and reinforcing gender inequalities [12-14].

The second issue is the distortion in messages that recipients receive, with information materials generally not addressing the stakeholders appropriately. In some cases, messages target individuals in general, disregarding specific roles, knowledge, and experience that women and men have, and the fact that messages can potentially increase unpaid work that both parts are already involved in. It has been reported that one of the short-coming of approaches on the women, environment and development arena, including waste, has caused an increase in the unpaid housework and time burdens for women and girls, without them getting the benefits from such approaches $[2,15,16]$. The additional point is that information and education materials that are rooted in gender stereotypes, tend only to be directed at women, overlooking the importance of changing men's behavior and attitudes towards waste management activities $[2,11,17]$.

Connected with the previous issue, the third issue similarly arises when education strategies are directed at consumers and waste generators only, especially women. That phenomenon can also be understood as a critique and moralization of women, and yet again, an added burden to the unpaid reproduction work of female consumers, while exempting the other stakeholders (e.g., authorities, manufacturers, distributors, and retailers) from their responsibilities. Such occurrences are acknowledged as privatization as opposed to the socialization of waste management $[2,18]$.

There are several relevant gender research and practice works on natural resources use and management, as well as on sustainability $[5,10,19-26]$. Nonetheless, fewer initiatives focus on the waste management field, and among the existing ones, the availability of information is dated and limited [5,10,11,16,18,27-31]. Moreover, though selected projects have addressed the link between gender and waste, established resourceful and readily-available databases do not exist, and policies and programs, including educational initiatives, have yet to articulate the fundamental questions about gender. In a systematic review analysis of academic journal articles on waste education and the inclusion of the gender perspectives, researchers found that between 2007 and 2017, gender was superficially addressed, and mostly limited to the presentation of sex-disaggregated data to describe the studied groups [32]. Given that, it is timely to have studies, new theories, and reflections on the several aspects about waste and gender, as well as gender mainstreaming in national and local planning $[5,10,11,30]$. Thus, a question that can be posed is, how can the academic and practice community be engaged in the development of waste education programs, and logically integrate gender perspectives and aspects? This paper potentially advances answers to that question, by first providing a closer look into the relationship between waste education and gender, and then proposing a framework for gender mainstreaming in waste education programs. The framework is a tool to guide the (before and after) assessment of the program cycle stages, and help identify the gender inequality unwanted effects and improve the implemented approaches for future initiatives.

The remainder of this paper is organized as follows. Sections 2 and 3 cover literature review on the topics of waste education and waste and gender. Meanwhile, Section 4 presents the grounds of the framework and the description of each component. The concluding points and limitations of the paper are summarized in Sections 5 and 6. 


\section{Waste Education}

Within the sustainable development agenda, waste management is one of the topics of Sustainable Consumption and Production (SCP), and in turn, waste education is a theme within Education for Sustainable Consumption (ESC) [33,34]. ESC has its focus on raising awareness and influencing consumer behavior by providing knowledge, values, and skills to individuals and social groups, with the goals to safeguard the quality of life, enable environmental protection, and provide for the efficient use of resources [33,35]. Education and awareness raising on waste are essential requirements to realize sustainable and effective waste management systems. Hence, public information initiatives and education programs are recognized activities of comprehensive management systems [36,37].

Delivering information on waste has an instructive and a motivating objective, which can be achieved using formal, non-formal, or informal avenues. The instructive one, aims at informing the stakeholders what to do, which is executed through national campaigns and local information by adopting conventional (e.g., posters, media campaigns), as well as innovative and artistic forms (e.g., street theatre, use of social media). On the other hand, the motivating objective has the function to call for stakeholders' attention to the problematic of waste and elucidate their role as part of the solution $[38,39]$. Therefore, practitioners in the field of waste management should work alongside education professionals to define and design, form, and methodize proper waste management and education strategies [40].

Moreover, the participation of stakeholders such as the government, private sector, civil society, academia, and the public in the development processes for waste education is required. Their participation ensures political and financial support, facilitates involvement, promotes transparency and accountability, and fosters trust and cooperation from the public [38,41]. Also relevant is the design of specific and customized messages and information, to ensure that all stakeholders are aware of the waste issue and its implications [10,36]. Examples of comprehensive information and education strategies for waste management, considering primary stakeholder groups, are presented in Table 1.

Table 1. Selected waste education and information strategies for different stakeholder groups.

\begin{tabular}{|c|c|c|}
\hline Stakeholder Group & Education and Information Objectives & Types of Initiatives \\
\hline General public & $\begin{array}{l}\text { Address cultural practices and beliefs } \\
\text { Emphasize health benefits } \\
\text { Use simple messages and multiple media types } \\
\text { Build on existing community networks }\end{array}$ & $\begin{array}{l}\text { Information campaigns; Green shopping } \\
\text { guidance; Introduction of the waste topic } \\
\text { into the school curriculum }\end{array}$ \\
\hline Government authorities & $\begin{array}{l}\text { Emphasize the economic and health benefits of proper solid } \\
\text { waste management } \\
\text { Frame waste management activities as a topic of great interest } \\
\text { for electorates } \\
\text { Amplify the visibility and credibility of waste management } \\
\text { activities (e.g., by issuing uniforms to workers) } \\
\text { Emphasize the national policy impacts on local operations } \\
\text { Identify instances where local activities support national goals } \\
\text { Communicate about the national benefits of proper local waste } \\
\text { management (e.g., to attract investments) }\end{array}$ & $\begin{array}{l}\text { Institutional training and capacity } \\
\text { building to: } \\
\text { Improve health and safety work conditions } \\
\text { of formal waste workers and assess the } \\
\text { contribution of informal waste workers to } \\
\text { incorporate them into the waste } \\
\text { collection process. } \\
\text { Education and support for green } \\
\text { procurement programs }\end{array}$ \\
\hline Private sector & $\begin{array}{l}\text { Highlight the economic benefits to the private sector } \\
\text { Target groups with wide-ranging influence } \\
\text { (e.g., tourism boards) }\end{array}$ & $\begin{array}{l}\text { Information to waste treatment facilities; } \\
\text { Eco-labels; Marking of products } \\
\text { and components }\end{array}$ \\
\hline
\end{tabular}

\section{Waste and Gender}

Gender represents a social construction of the differences between women and men, as opposed to the consideration of biological characteristics. It determines the attribution of roles and functions, activities, social relations, behaviors, and norms for women and men in society, both in public and private life. There are a set of dynamic cultural determinations and characteristics that create the specific content of being women and men in each historical period, society, and culture $[16,43,44]$. Although both women and men contribute to social production and consumption activities, women often have multiple roles, which translate into inequality issues, particularly in the case of poor women. 
These roles mainly include providing basic needs and wellbeing at the household level through cleaning, cooking, educating children, handling livestock, and farming [5,11]. According to scholars and practitioners working in both the waste and gender fields, four main thematic areas are related to Waste and Gender: the gendered definition of waste; the gendered division of responsibilities for waste; community-based initiatives; and policy and practice [5,30,31].

\subsection{The Gendered Definition of Waste}

Women's and men's individual decisions are shaped by a combination of societal roles and expectations; hence, "waste" is not a (gender) neutral concept. Waste is defined as "something that has no more value" [31]. Nevertheless, what might be useless to an individual, can be considered a resource for enterprise or livelihood to others. For instance, in the household sphere, something that might look like dirt to men can be used as compost or fertilizer by women; and what looks like junk to women, can be used as motor parts to men. Moreover, knowledge of waste issues is different across gender and age. As reported in [30], "women, men, and children are almost certain to have different (and not always overlapping) knowledge of waste disposal places in their neighborhoods." Thus, in discussions and decisions on waste management, it is essential to clarify the different understandings and nuances of what waste and resources are for the target community $[5,30]$.

\subsection{The Gendered Division of Responsibilities for Waste}

The division of responsibilities in regard to waste management roles is also influenced by gender. In several spheres, women are required to be involved in clean up and waste handling activities in the household and at times in the community, without pay. For those who can afford it, they transfer these responsibilities to helpers. In contrast, men are more likely to only deal with waste when is directly connected to their daily activities, or when it is a remunerated effort $[5,11,16,28,30]$. At the household level, women are usually in charge of waste placement for collection and disposal, almost to the exclusion of men's participation due to the understanding that handling waste (especially without pay) will affect their status $[10,11]$. One of the outcomes is that women and children are the most exposed to the health hazards of handling waste, also considering that there are significant biological and behavioral differences between men and women, which influence the epidemiology and pathophysiology response to the exposure of products and substances such as hazardous chemicals and wastes $[1,27,45]$.

Moreover, even though women manage waste at home, there are underlying issues of power dynamics within all households. These issues can limit women's control and access to waste and create conflicts of interest, particularly when waste becomes a source of income $[11,28,31]$.

Another important aspect is the change of the responsibility and ownership that occurs, when the waste goes from being a household property to entering the existing waste management system, by being placed in the outside boundaries, termed 'point of set-out.' This change of boundary can also have implications for the women's autonomy and control of waste materials, and the transition from perceiving waste as a social responsibility to a technical one. Waste management guidelines and infrastructures are usually set up under the male gaze, which tends not to understand the needs and concerns of women regarding waste collection services. An instance where the outcomes of this structure can be observed is in the rise of issues related to the poor selection of location, time, and storage type for waste set-out points [11,30].

Lastly, women and children make a significant part of a large number of informal workers in developing countries dealing with waste collection, sorting, recycling, and selling valuable materials. As such, for women who are informal waste workers, the reproduction of hierarchical gender relations at home, in the workplace, and their respective communities, add to the commonly precarious conditions related to their work activities [46]. 


\subsection{Community-Based Initiatives}

Waste management at the community level is primarily related to the disposal activities at informal (illegal) dump sites and waste collection points, as well as public or communal space cleaning. Small-scale private and community-based enterprises, linked to formal enterprises and local authorities, are commonly in charge of these activities. Women's presence is prevalent by their responsibility to place the waste at the collection and dump sites, and the expectation for them to voluntary keep the community clean and maintain social harmony [16,18]. In cases where women move towards institutionalizing and monetizing their otherwise volunteer actions, a shift is usually seen, with men taking over and women being relegated to do stereotypical office work [10,30]. For example, in the e-mail discussion-conference on gender and waste organized by WASTE, Advisers on Urban Environment and Development, a participant noted that "in many Southeast Asian countries the women traditionally are responsible for the household waste and sweeping the streets and compound and take pride in keeping the environment clean and tidy. However, as soon as any of these tasks become paying jobs, men are either targeted for the jobs for various reasons or end up dominating the structures and decision-making systems" [31]. It is also observed that women that participate in waste activities as paid workers are underpaid, work in dangerous social and human conditions, and at times have to take their children to work alongside them. Linked with that is a reinforced cycle that they might face: the work being assigned has low social status, resulting in low pay, then, being paid less, thus being considered low-class citizens $[4,11,16,29,30]$.

Furthermore, women's transition from informal waste picking to micro-enterprising is often faced with limited access to financial resources and family support, and singular association with specific materials such as plastic and textiles, as opposed to other types of materials, of which management is resource-intensive and physically demanding, such as metals and construction debris. Another current issue of social-economic nature is that the participants in women's community initiatives are usually part of the middle and upper classes. These women usually also have connections to the local NGOs and power structures, which can relegate the needs and contribution of women from lower classes [3,5,30]. An example in India regarding affirmative action for leadership positions in local decision-making institutions indicated that "the women belonging to the elite class are more likely to enter local politics, and that they do not necessarily represent poor women's interests" [14].

\subsection{Policy and Practice}

Due to women's often restricted access to public positions and political participation, their views and needs are often not taken into account [47]. Notwithstanding women's relatively high involvement in waste management activities at the local level, integration in the decision-making processes is often (intentionally and unintentionally) neglected. Conversely, men are more likely to have access to decision-making institutions and therefore have their say on policy design, municipal infrastructure and technology planning, selection of service levels, and payment plans [11,28,29]. Also, project funders and managers, seem to lack awareness about the relevance of including gender analysis in the conception, implementation, and assessment of waste programs [30].

The underlying power and societal structures, as well as a lack of political will, are then reflected in the absence of consideration for the practical gendered needs and the strategic gender needs of women in waste management policy, information and education practice [2,14]. These two concepts of gender needs (or interests) were first introduced by Maxine Molyneux in 1985, with some arguing that those often overlap. Practical gender needs refer to responding to an immediate perceived necessity in a specific context, without changing the existing gender division of labor or challenging women's subordinate position in society despite these being the causes of women's practical gender needs. General actions to address these needs are related to the improvement of living and working conditions, including water, healthcare, essential housing services, and employment provision, as well as the distribution of food. Meanwhile, strategic gender needs are those that, if met, would transform the unequal power imbalance between women and men. Strategic gender needs vary according 
to circumstances and relate to gender divisions of labor, power, and control. Some of the general issues it addresses include legal rights, domestic violence, equal pay, and women's control over their bodies $[13,14,48]$. For example, in regards to the practical needs of women working in the waste sector, those include the need to improve: work conditions, access to credit, legitimacy status of entrepreneurial initiatives, protection against harassment and, negotiation conditions with authorities and other stakeholders. On the other hand, strategic gender needs relate to addressing the social and cultural barriers to conduct business outside of the household sphere and shift the power relationships with the male-controlled waste management structures $[30,46,48]$.

\section{A Conceptual Framework for Gender Mainstreaming in Waste Education Programs}

In the following, we describe the conceptual framework designed as a gender mainstreaming tool for waste education programs, based on the literature on waste education, and gender and waste. Gender mainstreaming is coined as accounting for the different needs and conditions of women and men, ensuring their rightful participation, and assessing the implications of the planned (waste) policies, strategies, and management interventions, to achieve gender equality $[43,44,47,49]$.

The realization of education programs, similarly to other types of programs and projects, is a systematic, iterative process, mainly comprised of situational analysis and needs assessment, definition and planning, implementation, and monitoring and evaluation [50-52]. These stages overlap and interrelate, and the results of the previous one become the inputs for the next stage [51]. In the proposed framework, adding to the four program stages, an institutional component is included to assess the gender stances and the possible work structures of the program's promoting entity.

Within the framework, the common premise and key requirement for all stages of the program is the inclusion of participatory approaches with gender equality aspects. Participatory approaches allow for interactions, co-learning, and fair representation of stakeholders such as researchers, program managers, target groups, and policymakers, leading to continuous improvement and adaptation of plans and actions for the particular program [14,26,53]. Besides this, they usually imply iterative interactions between project promoters and local stakeholders to clarify the specific needs for intervention, and to plan for said intervention and the subsequent evaluation of the outcomes [26,54]. In turn, participation with gender equality considerations aims to facilitate recognition of local knowledge, a process that explicitly includes both men and women from different age groups, which relies on horizontal communication for data collection [48]. Horizontal communication relates to the exchange between individuals, free of consideration of hierarchical aspects, which is mainly characterized by being activity-related and informal [55]. Furthermore, it ensures that the target group is addressed as heterogeneous, with different and at times with conflicting understandings and experiences on the issue, all the while empowering the least powerful groups by enabling their participation in the program development process. As such, the promoting team should be knowledgeable of gender issues, acknowledge the local knowledge from women and men, and be in direct contact with the target group [48]. Practical aspects related to participation with gender equality include $[14,19,44,48,56]$ :

- Creating different opportunities and spaces for women and men (groups according to aspects such as age, marital status, parentage, sexual orientation social composition, when necessary), to present their views and contributions, as well as the opportunity to integrate their inputs collectively.

- Ensure enabling environments, as it relates to the availability of participation, e.g., criteria, time, location.

- The process should also be as transparent as possible, to create adhesion and ownership, with women and men encouraged to participate in the authentication and explanation of the program development. 
Mainstreaming gender in waste programs mainly translates into the integration of both genders' views and priorities for waste, improvement of the division of responsibilities and access to waste handling resources, creation of employment opportunities, and the inclusive participation of women and men in decision-making processes. As such, the inclusion of gender perspectives in waste management and education is a twofold strategy. It should address the untapped potential of women's contribution to solving operational problems of waste systems, as well as the specific issues of gender inequality related to the system $[1,5,28,30]$. Thus, the framework presented in Figure 1 builds on the three previously presented critical issues of waste education and gender:

I. Full participation of women and men in all stages of the program

II. Design and delivery of gender-aware messages; and,

III. Assignment of responsibility among stakeholders.

\begin{tabular}{|c|c|c|c|}
\hline $\begin{array}{l}\text { Program rationale } \\
\text { and background }\end{array}$ & $\begin{array}{ll}\text { - } & \text { Waste type (What) } \\
& \text { Target group (Who) } \\
& \text { Relevance (Why) } \\
\text { - } & \text { Geriod and location (When \& Where) } \\
\end{array}$ & & \\
\hline Components & \multicolumn{2}{|l|}{ Main Issues } & Methodological approaches and tools \\
\hline $\begin{array}{l}\text { Promoting/managing } \\
\text { entity }\end{array}$ & \multicolumn{2}{|l|}{$\begin{array}{l}\text { Team composition } \\
\text { Institutional and individual gender awareness level } \\
\cdot \quad \text { Policies, training, gender units or experts } \\
\text { Knowledge of waste and gender issues }\end{array}$} & $\begin{array}{l}\text { Gender analysis } \\
\text { Gender equality capacity assessment }\end{array}$ \\
\hline \multirow{4}{*}{$\begin{array}{l}\text { Situation analysis and } \\
\text { needs assessment }\end{array}$} & \multicolumn{2}{|c|}{$\begin{array}{l}\text { General background of target group: Demographic, socio, economic, ecologic, political, legal, historical } \\
\text { and cultural profile }\end{array}$} & \multirow[b]{3}{*}{$\begin{array}{l}\text { Gender analysis } \\
\text { Material flow analysis } \\
\text { Gender statistics } \\
\text { Stakeholder analysis }\end{array}$} \\
\hline & Content & Operational & \\
\hline & $\begin{array}{l}\text { Municipal and Community level } \\
\text { - } \quad \text { Waste flows } \\
\quad \text { Stakeholders groups: role, needs, power, interest, } \\
\text { priorities } \\
\text { - Existing waste related initiatives } \\
\text { - Gender policies }\end{array}$ & $\begin{array}{l}\text { - Gender (age, education level, class, } \\
\text { and other relevant aspects) } \\
\text { representativeness in the } \\
\text { municipal and community } \\
\text { decision-making bodies } \\
\text { - Gender awareness level } \\
\text { - Existing gender-specific groups and } \\
\text { NGOs }\end{array}$ & \\
\hline & $\begin{array}{l}\text { Household level } \\
\text { - Women and Men: role and practice, needs, interest, } \\
\text { priorities, and access to waste related resources } \\
\text { - Awareness level on waste issues }\end{array}$ & $\begin{array}{l}\text { - Willingness to participate in } \\
\text { decision-making processes for } \\
\text { waste } \\
\text { Capacity and factors influencing } \\
\text { participation - opportunities and } \\
\text { limitations }\end{array}$ & $\begin{array}{l}\text { Waste walk-through } \\
\text { Gender stakeholder consultation and } \\
\text { analysis } \\
\text { Gender Impact assessment }\end{array}$ \\
\hline \multicolumn{4}{|c|}{$\begin{array}{l}\text { Potential gender-differentiated impacts of the program - distribution of paid and unpaid waste related work; household gender dynamics; sanitary conditions; } \\
\text { representativeness in decision-making processes; assess of waste resources, other relevant aspects. }\end{array}$} \\
\hline $\begin{array}{l}\text { Definition and } \\
\text { planning }\end{array}$ & $\begin{array}{ll}\text { - } & \text { Gender-specific goals and objectives } \\
\text { - } & \text { Program activities, budgeting, and outputs } \\
\end{array}$ & \multirow{3}{*}{$\begin{array}{l}\text { Gender equality training for } \\
\text { program personnel and target } \\
\text { group participants } \\
\text { Conditions for participation from } \\
\text { target group - time; location; } \\
\text { communication strategies } \\
\text { Gender-balance of program } \\
\text { personnel and target group } \\
\text { participants }\end{array}$} & \multirow{3}{*}{$\begin{array}{l}\text { Gender equality capacity assessment } \\
\text { Gender indicators } \\
\text { Gender budgeting } \\
\text { Gender Impact assessment }\end{array}$} \\
\hline Implementation & - Gender-sensitive messages & & \\
\hline $\begin{array}{l}\text { Monitoring and } \\
\text { evaluation }\end{array}$ & $\begin{array}{l}\text { - Assessment of gender indicators } \\
\text { Assessment of target group expectations against the } \\
\text { objectives PGN }\end{array}$ & & \\
\hline
\end{tabular}

Figure 1. Framework for mainstreaming gender in waste education programs.

Gender awareness is understood as the ability to view society from the perspective of gender roles and understand how this has affected women's needs in comparison to the needs of men [57].

\subsection{Mainstreaming Gender in the Promoting Entity}

Irrespective of the commitment to gender equality, societal bodies are not gender-neutral. Gender-neutral refers to various aspects such as language and concepts, not having an association with either men or women [11,58]. In the organization's context, traditional and critical approaches have its origins in the male domain, and as a result, are male-centered [4]. Government institutions, civil society organizations, consultants, training organizations, private enterprises, among others, have their institutional culture, values, and experience. Therefore, their views on gender issues are 
based on their identifiers, and the women and men that are part of those institutions will either support or challenge the principle of gender equality $[4,44]$. In the context of gender-aware waste education programs, it is relevant that the promoting entity has policies and strategies in place to address gender equality, and that the individuals part of it understand its importance, and are skillful of tools for gender integration into the program. Thus, it is necessary to assess the gender equality capacity of the entity conducting the waste education program.

Assessing gender in the promoting entity, at the institutional level, includes the evaluation of what gender policies, strategies, and procedures are in place. At the individual level, the focus is on the knowledge, skills, and attitudes on gender equality and the empowerment of women and the integration of these into the daily work. Also pertinent is the appraisal of the composition of the program personnel. The outcomes of this assessment clarify the needs and ways forward for institutional capacity development and training [47,59].

\subsection{Mainstreaming Gender throughout a Waste Education Program Cycle}

\subsubsection{Situation Analysis and Needs Assessment}

The design of an educational initiative often derives from the agreement that specific subjects are still misunderstood, or a particular environmental issue, such as waste, needs to be addressed [51]. Following the determination of the program rationale and background, i.e., the waste problem, target area, and population, the initial task is to analyze how the target waste is used and valued within society at large, and its value to both women and man, before and after the 'point of set-out.' These can be accomplished by conducting waste flow analysis and collecting waste walk-through information from women and men, and by determining the roles, level of awareness in matters of waste management, and involvement in the decision-making process [31,60]. Moreover, it is crucial to clarify how women and men are affected by different political, social, cultural, historical, and legal factors about the given waste problem, what their respective needs are, and their access to use and control resources, goods, and services, related to the target waste [47].

The fundamental goal of this phase is to identify the waste problems, and the opportunities, strengths, challenges, and possible new directions, while deciphering the gender structures that surround these problems, thus avoiding the conception of discriminatory gender programs.

\subsubsection{Definition and Planning}

Following the needs assessment, the next stage is the definition of the primary goal and specific objectives of the program, as well as the details on how these are going to be accomplished [51]. Here, women and men should be called upon to reflect and discuss their priorities for change, to identify their views on how the program should be implemented, and to share their expectations on the program outcomes. It is relevant to assess if the objectives reflect the needs of women and men, if these address gender issues in any way, and also if all genders will benefit from the program (in case it is not a gender-specific program). Also necessary, is making sure of the introduction of gender-specific designs and gender-sensitive approaches on the education materials [61].

In this stage, resource and technical needs that can facilitate the application of gender perspectives are included, such as the introduction of gendered budgeting, procurement, training, and indicators. The selection and development of relevant gender indicators are particularly crucial because progress for each program's objective can be tracked, ensuring, therefore, gender balance within the results $[44,49,53]$.

\subsubsection{Implementation}

This stage included the materialization of the program, the efficient application of resources, and guaranteeing full stakeholders' participation. Central to this stage is the evaluation of gender balance and explicit connections between gender and waste education, and that the message reaches 
all stakeholders effectively while ensuring that gender-sensitive language is used to deliver the information. It also includes tracking the implications of the program on gender aspects, by collecting feedback from the target group or program beneficiaries $[47,53]$.

\subsubsection{Monitoring and Evaluation}

Comprising the systematic information gathering on the activities, characteristics, and results of the program, in regard to gender issues $[47,51]$, monitoring and evaluation in a gender perspective is a reflection tool to aid decision-making regarding the planned developments, inclusive of the promoting entity and the participant stakeholders [62]. Of importance is the concurrent need to understand if the education program brought about positive effects related to the waste issue that it was developed for, to both women and men, and if the project had any impact on gender issues. At this point, the indicators selected on the definition and planning stage are measured and evaluated against the program objectives, with data collected from all involved stakeholders. Moreover, monitoring and evaluation can be used as an iterative process to improve upon education programs $[44,47,51]$.

\section{Conclusions}

Integrating gender perspectives into waste management elements such as education programs has the potential to improve effectiveness, avoid costly mistakes, and ensure equitable access to livelihoods, resources, or benefits deriving from a project [47].

This paper detailed a novel conceptual framework for gender mainstreaming in waste education programs, addressing inclusive participation in decision-making processes, gender-aware content, and stakeholders' accountability. The framework is a tool to aid in the investigation on how to realize the potential twofold role gender inclusion has on the effectiveness of waste education programs and on ensuring gender equality through the program cycle. It fits participatory assessments of the promoting entity, as well as four stages of education programs: needs assessment, definition and planning, implementation, and monitoring and evaluation.

\section{Future Research and Limitations of the Study}

The next stage of this endeavor will entail piloting the feasibility of the framework through its application in concluded, ongoing, and intended waste education programs, in several locations worldwide. Lastly, intersectionality issues of gender and cultural, racial, class, sexuality, (dis)ability, and ethnic identities are not explored and considered in the proposed framework. It is then critical to further understand the influence and power dynamics about the different identity markers between and within genders. Moreover, this study does not consider genders other than male and female. Future research addressing these limitations is required.

Author Contributions: Conceptualization, L.S.d.M. and P.V.; methodology, L.S.d.M.; software, N/A; validation, L.S.d.M. and P.V.; formal analysis, L.S.d.M.; investigation, L.S.d.M.; resources, L.S.d.M.; data curation, L.S.d.M.; writing-original draft preparation, L.S.d.M.; writing-review and editing, L.S.d.M. and P.V.; visualization, L.S.d.M. and P.V.; supervision, P.V.; project administration, L.S.d.M.; funding acquisition, L.S.d.M.

Funding: This research was funded by JAPAN SOCIETY FOR THE PROMOTION OF SCIENCE, via its KAKENHI grant, number JP17F17779.

Acknowledgments: The authors express their gratitude for the contributions offered by the anonymous reviewers of this manuscript.

Conflicts of Interest: The authors declare no conflict of interest.

\section{References}

1. United Nations Environment Programme (UNEP). Global Gender and Environment Outlook; United Nations Environment Programme: Nairobi, Kenya, 2016. 
2. Schultz, I.; Stieß, I. Policies to Promote Sustainable Consumption Patterns WP 1: 'Gender Aspects of Sustainable Consumption Strategies and Instruments'; Institute for Social-Ecological Research (ISOE): Frankfurt/Main, Germany, 2009.

3. Gough, A. Researching Differently: Generating a Gender Agenda for Research in Environmental Education. In International Handbook of Research on Environmental Education; Stevenson, R.B., Brody, M., Dillon, J., Wals, A.E.J., Eds.; Routledge: Abingdon-on-Thames, UK, 2013; pp. 375-383.

4. Acker, J. Hierarchies, jobs, bodies: A theory of gendered organizations. Gend. Soc. 1999, 4, 139-158. [CrossRef]

5. Tiwari, N. Gender Roles in Environmental Household Waste Management: A Case Study in Palmerston North, New Zealand. Ph.D. Thesis, Massey University, Palmerston North, New Zealand, 2001.

6. Saraçli, S.; Yilmaz, V.; Arslan, T. The Effects of Mothers' Educational Levels on University Students' Environmental Protection Commitments and Environmental Behaviors. Eur. J. Educ. Res. 2014, 55, 177-199. [CrossRef]

7. Piñeiro, C.; Díaz, M.-J.; Palavecinos, M.; Alonso, L.-E.; Benayas, J. Responsible consumption with a gender perspective: Consumption discourse and practices surrounding gender equality and sustainability in Madrid / Consumo responsable con perspectiva de género. Discursos y prácticas de consumo en torno a la equidad. Psyecol. Rev. Bilingüe Psicol. Ambient./Biling. J. Environ. Psychol. 2014, 5, 252-283. [CrossRef]

8. Gough, A.; Russell, C.; Whitehouse, H. Moving gender from margin to center in environmental education. J. Environ. Educ. 2017, 48, 5-9. [CrossRef]

9. United Nations Statistics Division (UNSD). Glossary of Terms-Gender Statistics Wiki. 2015. Available online: https:/ / unstats.un.org/unsd/genderstatmanual/Glossary.ashx (accessed on 11 July 2018).

10. Wilson, D.C.; Rodic, L.; Modak, P.; Soos, R.; Carpintero, A.; Velis, K.; Simonett, O. Global Waste Management Outlook; United Nations Environment Programme (UNEP): Nairobi, Kenya, 2015.

11. Gender and Water Alliance (GWA) and WASTE. No capacity to waste. In Training Module Gender and Waste; GWA: Dieren, The Netherlands, 2010.

12. Rouhani, L. Unpacking Community Participation: A Gendered Perspective. Curr. Issues Comp. Educ. 2017, $20,31-44$.

13. March, C.; Smyth, I.; Mukhopadhyay, M. A Guide to Gender-Analysis Frameworks; Oxfam Publishing: Oxford, UK, 1999; p. 144.

14. Akerkar, S. Gender and Participation; Institute of Development Studies: Brighton, UK, 2001.

15. Asian Development Bank. Balancing the Burden? Desk Review of Women's Time Poverty and Infrastructure in Asia and the Pacific; Asian Development Bank: Mandaluyong City, Philippines, 2015.

16. Samson, M. Dumping on Women: Gender and Privatisation of Waste Management; Municipal Services Project (MSP) and the South African Municipal Workers' Union (Samwu): Gauteng, South Africa, 2003.

17. Autio, M.; Heiskanen, E.; Heinonen, V. Narratives of 'green' consumers-The antihero, the environmental hero and the anarchist. J. Consum. Behav. 2009, 8, 40-52. [CrossRef]

18. Fredericks, R. Gender and the Politics of Trash in Dakar: Participation, Labor and the 'Undisciplined' Woman; Thinking Gender Papers; UCLA Cent. Study Women: Los Angeles, CA, USA, 2008.

19. United Nations Development Programme (UNDP). Gender and Energy for Sustainable Development: A Toolkit and Resource Guide; United Nations Development Programme (UNDP): New York, NY, USA, 2004.

20. Luna, M.; Aguilar, L.; Gilligan, M.; Owren, C.; Prebble, M.; Westerman, K. Women in Environmental Decision Making: Case Studies in Ecuador, Liberia, and the Philippines; The Global Gender Office of IUCN and Conservation International: Washington, DC, USA, 2015; p. 78.

21. Asian Development Bank. Checklist for water Supply and Sanitation; Asian Development Bank: Mandaluyong City, Philippines, 2006.

22. Meinzen-Dick, R.; Kovarik, C.; Quisumbing, A.R. Gender and Sustainability. Annu. Rev. Environ. Resour. 2014, 39, 29-55. [CrossRef]

23. Sexsmith, K. Towards Gender Equality in Global Sustainable Consumption and Production Agreements. In Women Reclaiming Sustainable Livelihoods; Harcourt, W., Ed.; Palgrave Macmillan: London, UK, 2012; pp. 42-61.

24. Fonjong, L.N. Gender Roles and practices in natural resource management in the North West Province of Cameroon. Local. Environ. 2008, 13, 461-475. [CrossRef] 
25. Garcia, A.S.; Wanner, T. Gender inequality and food security: Lessons from the gender-responsive work of the International Food Policy Research Institute and the Bill and Melinda Gates Foundation. Food Secur. 2017, 9, 1091-1103. [CrossRef]

26. Graef, F.; Hernandez, L.E.A.; König, H.J.; Uckert, G.; Mnimbo, M.T. Systemising gender integration with rural stakeholders' sustainability impact assessments: A case study with three low-input upgrading strategies. Environ. Impact Assess. Rev. 2018, 68, 81-89. [CrossRef]

27. The Secretariat of the Basel Rotterdam and Stockholm Conventions. Gender Heroes: From grassroots to global action. In A Collection of Stories Featuring Gender Perspectives on the Management of Hazardous Chemicals and Wastes; Secretariats of the Basel, Rotterdam, Stockholm Conventions (BRS): Châtelaine GE, Switzerland, 2015.

28. Woroniuk, B.; Schalkwyk, J. Waste Disposal E Equality between Women and Men; Swedish International Development Cooperation Agency (SIDA): Stockholm, Sweden, 1998.

29. IETC. Gender and Waste Management Did You Know ... ? Available online: https://www.ctc-n.org/sites / www.ctc-n.org/files/resources/gender_and_waste_management.pdf (accessed on 1 March 2019).

30. Muller, M.S.; Scheinberg, A. Gender and Waste Electronic Discussion Group, 9-31 May 1998 A Summary; WASTE: Gouda, The Netherlands, 1998.

31. Scheinberg, A.; Muller, M.; Tasheva, E. Gender and Waste. In Integrating Gender into Community Waste Management: Project Management Insights and Tips from an E-mail Conference; WASTE: Gouda, The Netherlands, 1999.

32. Muchangos, L.S.D.; Vaughter, P. Are gender perspectives included in waste education programs? A systematic literature review. In Proceedings SUM2018, Fourth Symposium on Urban Mining; CISA Publisher: Bergamo, Italy, 2018.

33. Thoresen, V.W. HERE and NOW! Education for Sustainable Consumption: Recommendations and Guidelines; United Nations Environment Programme (UNEP): Paris, France, 2010; pp. 1-36.

34. United Nations Environment Programme (UNEP). ABC of SCP Clarifying Concepts on Sustainable Consumption and Production; UNEP: Paris, France, 2010.

35. Didham, R.J.; Choi, M.Y. Education for Sustainable Consumption: Effective Strategies to Promote Responsible Consumer Behaviour; Institute for Global Environment Strategies: Kanagawa Prefecture, Japan, 2010; pp. 1-17.

36. Climate and Clean Air Coalition (CCAC). Raising Awareness about Solid Waste Management; CCAC: Paris, France, 2013.

37. United Nations Environment Programme (UNEP). Solid Waste Management; United Nations Environment Programme (UNEP): Osaka/Shiga, Japan, 2005.

38. Associação Brasileira de Empresas de Limpeza Pública e Resíduos Especiais (ABRELPE) and International Solid Waste Association (ISWA). Solid Waste: Guidelines for Successful Planning; ABRELPE \& ISWA: Sao Paulo, Brazil, 2013; p. 52.

39. Rodic, L.; Wilson, D.C. Resolving governance issues to achieve priority sustainable development goals related to solid waste management in developing countries. Sustainability 2017, 9, 404. [CrossRef]

40. Polanec, B.; Aberšek, B.; Glodež, S. Informal Education and Awareness of the Public in the field of Waste Management. Procedia Soc. Behav. Sci. 2013, 83, 107-111. [CrossRef]

41. Muchangos, L.S.D.; Tokai, A.; Hanashima, A. Application of the Delphi Method to the Identification of Barriers to a Waste Management Policy in Maputo City, Mozambique. J. Sustain. Dev. 2015, 8, 146-157. [CrossRef]

42. Tojo, N.; Neubauer, A.; Bräuer, I. Waste Management Policies and Policy Instruments in Europe-An Overview; Lund Universit: Lund, Sweden, 2006.

43. Alfaro, M.C. Unveiling Gender: Basic Conceptual Elements for Understanding Gender, 1st ed.; ABSOLUTO: San José, Costa Rica, 1999.

44. Swiss Agency for the Development and Cooperation (SDC). Gender in Practice-A Toolkit for SDC and Its Partners; Federal Department of Foreign Affairs (FDFA) Swiss Agency for the Development and Cooperation: Bern, Switzerland, 2003.

45. Regitz-Zagrosek, V. Sex and gender differences in health. Science \& Society Series on Sex and Science. EMBO Rep. 2012, 13, 596-603. [PubMed] 
46. Dias, S.; Ogando, A.C. From Theory to Action: Gender and Waste Recycling: A Toolkit for Teachers, Researchers and Practitioners Book 3: Resources; Women in Informal Employment: Globalizing and Organizing (WIEGO): Belo Horizonte, Brazil, 2015.

47. Organization for Security and Co-operation in Europe (OSCE). Gender and Environment. A Guide to the Integration of Gender Aspects in the OSCE's Environmental Projects; OSCE: Vienna, Austria, 2009.

48. Aguilar, L.; Briceno, G.; Valenciano, I. Seek and ye Shall Find: Participatory Appraisal with a Gender Equity Perspective, 1st ed.; International Union for Conservation of Nature (IUCN): San José, Costa Rica, 2000.

49. European Institute for Gender Equality. Gender Impact Assessment: Gender Mainstreaming Toolkit; Publications Office of the European Union: Luxembourg, 2016.

50. Canadian Cardiovascular Society. A Handbook for Planning Committees Developing Educational Programs; Canadian Cardiovascular Society: Ottawa, ON, Canada, 2012.

51. National Oceanic and Atmospheric Administration (NOAA). Designing Education Projects: A Comprehensive Approach to Needs Assessment, Project Planning and Implementation, and Evaluation; NOAA: Silver Spring, MD, USA, 2009; p. 99.

52. The Institute of Progressive Education and Learning. Curriculum Development Cycle. Available online: http: / institute-of-progressive-education-and-learning.org/k-12-education-part-ii/k-12-curriculum/ curriculum-development-cycle/ (accessed on 14 February 2019).

53. Aguilar, L. A Good Start Makes a Better Ending: Writing Proposals with a Gender Perspective, 1st ed.; International Union for Conservation of Nature (IUCN): San José, Costa Rica, 1999.

54. Bradbury-Huang, H. What is good action research? Why the resurgent interest? Action Res. 2010, 8, 93-109. [CrossRef]

55. Pruyn, A.; Peters, O.; Bartels, J.; de Jong, M.; van der Molen, M. Horizontal and vertical communication as determinants of professional and organisational identification. Pers. Rev. 2010, 39, 210-226.

56. Gurung, M.; Leduc, B. Guidelines for a Gender Sensitive Participatory Approach; Icimod: Lalitpur, Nepal, 2009; pp. 1-4.

57. European Institute for Gender Equality. Gender Awareness; Gender Equality Glossary and Thesaurus: Vilnius, Lithuania, 2018; Available online: http:/ / eige.europa.eu/rdc/thesaurus / terms / 1147 (accessed on 11 July 2018).

58. Kabeer, N. Agency, well-being \& inequality: Reflections on the gender dimensions of poverty. IDS Bull. 1996, 27, 11-21.

59. Lahousen, V.; Popovic, N. Gender Equality Capacity Assessment, 2nd ed.; UNWomen: New York, NY, USA, 2016.

60. Anschütz, J.; Jgosse, J.I.; Scheinberg, A. Putting Integrated Sustainable Waste Management into Practice; WASTE: Gouda, The Netherlands, 2004.

61. Public Awareness \& Communication Modules and Materials. Available online: http://www.gdrc.info/ docs/waste/012.pdf (accessed on 1 March 2019).

62. Rodríguez, G.; Meléndez, N.; Velázquez, E.; Fuentes, M.A. Taking the Pulse of Gender: Gender-Sensitive Systems for Monitoring and Evaluation, 1st ed.; International Union for Conservation of Nature (IUCN): San José, Costa Rica, 2000.

(C) 2019 by the authors. Licensee MDPI, Basel, Switzerland. This article is an open access article distributed under the terms and conditions of the Creative Commons Attribution (CC BY) license (http:// creativecommons.org/licenses/by/4.0/). 